\title{
USAHA DONAT BAKAR DI DELI SERDANG
}

\author{
Riana Friska Siahaan $^{1 *}$, Siti Wahidah ${ }^{1}$ \\ ${ }^{1}$ Jurusan Pendidikan Kesejahteraan Keluarga, Fakultas Teknik, Universitas Negeri Medan, \\ Jl. Willem Iskandar pasar V-Kotak Pos No. 1589 - Medan 20221 \\ Penulis Korespodensi: Riana Friska@yahoo.co.id
}

\begin{abstract}
Abstrak
Tujuan kegiatan ini : (1) Memberikan mesin pencampur adonan dan alat pemanggang kue (oven deck) guna membantu mitra memproduksi donat; (2) Memberikan inovasi baru pada usaha donat melalui pelatihan produksi donat bakar, sehingga jenis donat yang di produksi semakin banyak; (3) Memberikan pelatihan menajemen usaha sehingga dapat meningkatkan produksinya. Mitra kegiatan yaitu Usaha Donat Mutiara dan Usaha Donat Citarasa di Kabupaten Deli Serdang. Kegiatan dilaksanakan selama 8 bulan tahun 2016. Metode Pelaksanaan adalah pendidikan, produksi, pelatihan manajemen usaha, penggunaan alat dan pendampingan. Hasil kegiatan yang diperoleh mitra mampu memproduksi donat bakar dengan berbagai kreasi. Peralatan yang diberikan kepada mitra dapat mempercepat produksi mitra. Pelatihan manajemen usaha yang diberikan dapat memperbaiki pembukuan keuangan mitra.
\end{abstract}

Kata Kunci: Usaha, Donat, Bakar

\begin{abstract}
The purpose of this activity: (1) Providing mixing machines and oven to help partners produce donuts; (2) Providing new innovations to donut business through training in the production of grain donuts, so that the types of donuts in production more and more; (3) Providing business management training so as to increase production. Activity Partners are Donut Donut Business and Donate Cuisine Business in Deli Serdang Regency. Activities are implemented for 8 months in 2016. Implementation methods are education, production, business management training, tool usage and assistance. The results of activities obtained by the partners are able to produce donuts with a variety of fruits creations. Equipment provided to partners can accelerate partner production. The business management training provided can improve the financial bookkeeping of partners.
\end{abstract}

Keywords: Businesses, Doughnuts, Roasted

\section{PENDAHULUAN \\ Analisis Situasi}

Bisnis kuliner memang tak ada matinya. Setiap hari ada saja kreasi baru di dunia kuliner yang membuat masyarakat tergiur untuk mencicipinya. Banyak pula kalangan masyarakat yang gemar berwisata kuliner untuk mencicipi ragam kuliner unik khas Indonesia. Bisnis kuliner boleh dikatakan sebagai bisnis yang gampang-gampang susah. Modal yang relatif kecil dan diiringi dengan inovasi yang kreatif bukan mustahil menjadi langkah awal kesuksesan bisnis kuliner (Anonim $\left.^{(a)}, 2015\right)$.

Perkembangan bisnis kuliner beberapa tahun terakhir ini sangat spectakuler. Hal ini terbukti dengan pertumbuhan UKM di Indonesia yang didominasi oleh industri makanan dan minuman. Bahkan industri makanan dan minuman (Bisnis Kuliner) ini mengalami perkembangan yang signifikan di tahun 2009, dimana pertumbuhannya mencapai $11,22 \%$.

Bisnis kuliner memang menyedot perhatian banyak orang. Tidak hanya para konsumen saja yang ingin berlomba-lomba menikmati aneka hidangan lezat yang ditawarkan para pedagang, pelaku usaha makanan pun kini saling bersaing untuk memasarkan produknya (Sekar, 2013).

Donat sudah menjadi salah satu makanan favorit di Indonesia. Sebagai kudapan favorit, donat banyak dijajakan, baik di mal-mal maupun pinggir jalan. Sampai sekarang, masih banyak penjaja donat baru bermunculan. Mulai dari yang independen hingga yang ikut kemitraan atau waralaba dari merek-merek tertentu. Di tengah ketatnya persaingan, pemilik gerai donat gencar melakukan inovasi dengan meluncurkan produk-produk baru. Tujuannya adalah, agar pelanggan 
tidak bosan dengan rasa dan bentuk donat yang itu-itu saja (Junda, 2013).

Donat (doughnuts atau donut) adalah penganan yang digoreng, dibuat dari adonan tepung terigu, gula, telur dan mentega. Donat yang paling umum adalah donat berbentuk cincin dengan lubang di tengah dan donat berbentuk bundar dengan isi yang rasanya manis, seperti berbagai jenis selai, jelly, krim, dan custard (Marantina, 2015).

Donat merupakan salah satu makanan atau kue yang biasanya disukai oleh anak-anak. Namun sebenarnya jika cita rasa donat tersebut nikmat serta empuk pasti bukan hanya anak-anak yang menyukainya melainkan remaja dan orang dewasa pun bisa menyukainya. Cara membuat donat yang empuk dan nikmat tergolong mudah sekali. Bahan-bahan yang diperlukan juga cukup mudah ditemukan di pasar atau supermarket (Kusuma, 2013).

Donat Bakar adalah donat yang tersaji dalam keadaan masih panas dan fresh layaknya baru saja keluar dari penggorengan dengan lumeran cokelat yang masih meleleh. Donat bakar adalah produk inovatif, menarik, unik, enak, berkualitas dan menyenangkan dengan harga yang terjangkau. Donat ini banyak variasi toppingnya dan donat ditopping setelah dipesan pelanggan. yang unik dari donat bakar adalah menyajikan donat dalam keadaan hangat plus beraneka toping yang nikmat. Tidak hanya digoreng layaknya donat kebanyakan, proses pemasakan donat dengan cara dibakar. Sehingga memberikan sensasi kuliner donat yang unik dan nikmat (Kusuma, 2013).

Berdasarkan hal tersebut maka penulis perlu memberikan inovasi baru kepada mitra untuk pengembangan usahanya. Melalui kegiatan ini penulis ingin memberikan teknologi tepat guna kepada mitra melalui pembuatan donat bakar dan memberikan mesin mixer besar dan oven deck, sehingga hasil produksi mitra meningkat.

\section{Permasalahan Mitra}

Mitra kegiatan ini terdiri dari 2 mitra yaitu Usaha Donat Mutiara dan Usaha Donat Citarasa di Kabupaten Deli Serdang. Kelompok usaha donat ini menggunakan bahan baku dari tepung terigu, dalam pengolahan makanan perharinya bisa mencapai $50 \mathrm{~kg}$. Peralatan yang digunakan untuk mengolah donat ini masih sederhana, seperti untuk pencampur adonan masih menggunakan tangan secara manual. Donat ini biasanya di jual dengan harga bervariasi. Mulai harga Rp 500,-, Rp 1.000,- dan Rp 3.500,-. Usaha donat ini digemari oleh masyarakat karena rasanya yang enak dan harganya juga dapat dijangkau terutama anak-anak. Sistem pemasarannya masih terbatas, hanya dititipkan di warung-warung, dijual di pasar tradisional, di jual oleh pedagang kaki lima yang ada di sekitar sekolahan dan terkadang dijual kepada masyarakat yang mengadakan selamatan, pesta ataupun syukuran. Keberadaan usaha donat ini sebenarnya sangat menguntungkan bagi masyarakat sekitarnya karena dapat menyerap tenaga kerja sekitar 4-10 orang. Pekerja pada kelompok usaha kecil ini merupakan pekerja lepas atau pekerja harian dengan gaji perhari Rp 15.000,- perorang.

Berdasarkan kondisi mitra tersebut, yang menjadi permasalah mitra adalah diperlukannya teknologi tepat guna yaitu alat pencampur adonan dan alat pemanggang donat (Oven deck) dan pengembangan produk yaitu membuat donat bakar sehingga variasi dan rasa donat yang di produksi semakin banyak, dengan menggunakan teknologi tepat guna yang sederhana, murah dan mudah untuk melakukannya.

Bila dilihat kondisi manajemen yang diterapkan oleh mitra ini masih menggunakan manajemen sederhana secara kekeluargaan, dimana pengelolaan administrasi yang meliputi pengaturan kerja, pembiayaan, produksi dan SDM masih dilakukan secara sederhana. Untuk pengelolaan usaha ini, semuanya masih di pegang oleh pemilik usaha, baik pengadaan bahan baku, pengelolaan produksi, tenaga kerja, dan penjualan. Meskipun menganut manajemen kekeluargaan, sistem pembagian kerja sudah teroganisir dengan baik, artinya masing-masing pekerja sudah mempunyai tugas dan tanggungjawab untuk pekerjaan masing-masing. Melihat potensi donat ini cukup besar dan didukung dengan potensi sumberdaya alam. Maka diperlukan suatu upaya untuk memberdayakan pengusaha donat ini. Melalui teknologi tepat guna dan memberikan pengetahuan, pelatihan produksi, manajemen usaha dan pemasaran. Kegiatan yang akan dilakukan yaitu memberikan pengetahuan tentang donat bakar, teknik pengolahan donat bakar, manajemen usaha dan teknologi tepat guna, penggunaan alat pencampur adonan dan Oven deck yang secara langsung dapat mempengaruhi proses usaha donat bakar. Produk usaha donat ini akan menghasilkan donat bakar yang berkualitas, dapat mengurangi biaya produksi, sehingga dapat meningkatkan pendapatan pengusaha usaha donat.

\section{Persoalan Prioritas Mitra}

Berdasarkan pengamatan langsung dan wawancara dengan mitra usaha donat mereka menyatakan permasalahannya dalam hal produksi yaitu pengembangan usaha jenis donat. Usaha donat ini belum memiliki mesin (teknologi tepat guna) berupa mesin pencampur adonan dan alat pemanggang donat (Oven deck), dan manajemen usahanya masih sederhana. Berdasarkan bukti konkret berupa data-data, terus mengalami perkembangan sesuai dengan permintaan pasar. Hal inilah yang harus ditangani agar usaha ini lebih berkembang.

\section{Target dan Luaran}

1. Target luaran kegiatan program ini adalah dihasilkannya :

a. Mesin pencampur adonan

b. Alat pemanggang donat (Oven Deck)

c. Donat Bakar 
2. Spesifikasi Donat Bakar adalah :

a. Memiliki kandungan gizi: protein, karbohidrat, lemak, kalsium dan zat besi.

b. Higienis dan keamanan pangan terjamin.

\section{SpesifikasiAlat}

1. Spesifikasi Alat pencampur adonan

- Type: VFM-7B

- Listrik: 320 watt

- Kapasitas: 7 liter

- Kapasitas adonan; 0,75 Kg

- Berat: $22 \mathrm{Kg}$

2. Spesifikasi Oven deck : 2 pintu, ukuran lebar $85 \mathrm{~cm}$ $\mathrm{x}$ tinggi $55 \mathrm{~cm} \mathrm{x}$ panjang $85 \mathrm{~cm}$, termometer, fungsi : api atas dan api bawah.

\section{METODE PELAKSANAAN}

Metode Pelaksanaan yang dilakukan dalam kegiatan ini adalah metode pendidikan, metode pelatihan produksi, pelatihan manajemen usaha, penggunaan alat dan pendampingan. Berikut ini metode pelaksanaan dan penyelesaian permasalahan mitra yang dilaksanakan :

\section{Metode Pendekatan}

Berdasarkan permasalahan yang telah dikemukakan, maka metode pendekatan yang digunakan adalah metode pendidikan, metode pelatihan produksi, pelatihan manajemen usaha, penggunaan alat dan pendampingan. Dari permasalahan yang telah dikemukakan, dan untuk mencapai tujuan yang diharapkan, metode pendekatan untuk memecahkan masalah tersebut secara operasional sebagai berikut :

1. Memberikan pengetahuan tentang cara pengolahan donat bakar yang aman untuk di konsumsi dengan metode pendidikan dan penyuluhan pada mitra pengusaha donat. Donat bakar yang di produksi harus aman dan bebas dari bahan-bahan tambahan makanan yang berbahaya bagi kesehatan sehingga aman untuk dikonsumsi masyarakat.

2. Memberikan teknologi pengolahan donat bakar dan keamanan pangannya terjamin, dengan metode pendidikan, penyuluhan dan pelatihan produksi. Tujuan pelatihan produksi ini, memberikan pengetahuan kepada pengusaha donat bakar, sanitasi dan higiene makanan untuk meningkatkan mutu dan keamanan pangan, sehingga dapat di jadikan peluang pengembangan usaha.

3. Memberikan mesin pencampur adonan dan alat pemanggang donat (oven deck) serta metode pendampingan penggunaan alat pada pengusaha donat bakar. Alat dan Oven ini efektif dan efisien, operasinya mudah, sehingga dapat mengolah donat bakar.

4. Memberikan pelatihan manajemen usaha, dengan tujuan untuk meningkatkan keterampilan pemilik usaha (mitra) dalam menerapkan manajemen di bidang organisasi, produksi, keuangan, administrasi, harga jual produk, konsumen dan teknik pemasaran. Pelaku usaha ini biasanya adalah pemilik usaha yang memiliki fungsi ganda, karena itu manager dalam usaha ini berhadapan langsung dengan semua hal yang berkaitan dengan usaha, produksi, sumberdaya, pemasaran, pengembangan usaha dan lain-lain.

\section{Prosedur Kerja}

Prodesur kerja yang dilakukan untuk mendukung realisasi metode yang di tawarkan sebagai berikut:

1. Memberikan pendidikan pengolahan donat bakar yang aman untuk di konsumsi.

2. Memberikan pelatihan penggunaan mesin pencampur adonan dan alat pemanggang donat (oven deck).

3. Memberikan pelatihan produksi donat bakar.

4. Memberikan pelatihan cara pengolahan donat bakar untuk di jual kepada konsumen.

5. Memberikan pelatihan manajemen usaha dengan materi pelatihan yaitu :

- Pengetahuan dasar wirausaha

- Mengenali posisi usaha

- Konsep dasar marketing

- Komunikasi efektif dalam penjualan

- Fokus pada keunggulan produk

- Manajemen pegawai

- Monitoring pegawai

- Manajemen biaya UKM

- Menentukan harga produk dan harga jual

- Manajemen waktu dalam usaha

6. Pendampingan kegiatan.

\section{Luaran kegiatan :}

1. Luaran kegiatan ini dihasilkannya :

a. Alat pencampur adonan

b. Alat pemanggang donat (Oven Deck)

c. Donat Bakar

2. Spesifikasi donat bakar adalah :

a. Memiliki kandungan gizi : protein, karbohidrat, lemak, kalsium dan zat besi.

b. Higienis dan keamanan pangan terjamin.

3. Spesifikasi Oven deck : 2 pintu, ukuran lebar $85 \mathrm{~cm} \quad \mathrm{x}$ tinggi $55 \mathrm{~cm} \times$ panjang $85 \mathrm{~cm}$,termometer, fungsi : api atas dan api bawah.

\section{HASIL DAN PEMBAHASAN}

Bisnis kecil merupakan bisnis yang dioperasikan dan dimiliki secara independen dan tidak terlalu mendominasi pasar. Bisnis kecil memiliki kelompok bisnis utama, diantaranya jasa, konstruksi, keuangan dan asuransi, grosir, eceran, perakitan serta transportasi. Biasanya bisnis kecil dapat berkembang lebih cepat, hal ini disebabkan oleh konsep pemasaran yang tepat dan pertimbangan yang cermat atas tiap tiap elemen bauran pemasaran (Riyanikusuma,2010). Bisnis donat bakar termasuk ke dalam bisnis kecil, karena bisnis ini biasanya dimiliki oleh individu atau perorangan dan belum terlalu mendominasi pasar. 
Seperti teori di atas, bisnis ini dapat berkembang karena adanya bauran pemasaran yang cermat (Riyanikusuma,2010).

Semua orang mengenal donat, donat merupakan makanan yang berbentuk seperti cincin yang dipanggang kemudian diberi toping diatasnya. Itu merupakan hal yang sudah biasa, tetapi sekarang ada kreasi baru yang dapat meningkatkan penjualan produk donat yaitu donat bakar. Donat bakar merupakan suatu produk makanan yang banyak digemari oleh masyarakat (konsumen) dan memiliki perbedaan dari donat donat yang lain. Perbedaan tersebut terletak pada proses pembuatannya yaitu donat dibakar terlebih dahulu sebelum diberi topping, sehingga konsumen bisa menikmati sensasi donat dalam keadaan hangat dengan lumeran cokelat yang begitu lezat serta menggoda dengan berbagai varian rasa. Donat bakar memiliki bermacam-macam variasi rasa seperti jagung bakar, balado, blueberry, durian, cokelat glaze, cappucino, tiramisu, kacang, keju, donat ala burger, sosis sapi, dan lain lain. Saat ini Donat bakar telah memiliki 29 variasi rasa, dan akan terus dikembangkan diwaktu mendatang (Riyanikusuma,2010).

Hasil dari proses produksi yang dirancang untuk memenuhi kebutuhan dan keinginan konsumen. Yang harus diperhatikan dalam suatu produk adalah bagaimana menciptakan ciri atau citra yang membuat produk berbeda dari pesaing. Penetapan harga adalah strategi menyeleksi harga yang paling tepat untuk menjual produk. Harga donat bakar ini berkisar dari Rp 3000,00 sampai Rp 13000,00. Harga ini ditinjau dari bahan bahan yang digunakan dalam pembuatan donat. Selain ditinjau dari segi bahan bahannya, penetapan harga ini juga ditinjau dari berapa banyak perlengkapan yang menunjang dalam penjualan donat bakar ini (Riyanikusuma,2010).

Pemasaran donat bakar ini, biasanya bertempat di depan sekolah dan pusat perbelanjaan. Dua tempat ini merupakan tempat yang strategis dalam pemasaran donat bakar ini, karena tempat ini merupakan tempat yang ramai, dan dapat menarik konsumen yang banyak (Riyanikusuma,2010).

Promotion adalah kegiatan untuk memperkenalkan suatu produk atau jasa pada pasar sasaran, untuk membangun persepsi pelanggan mengenai produk atau jasa yang ditawarkan. Konsep promosi yang biasa digunakan antara lain periklanan, public relation, promosi penjualan, menjual sendiri produk tersebut, serta pemasaran langsung (Riyanikusuma,2010).

Pelaksanaan kegiatan dibagi dalam tiga tahap yaitu tahap persiapan, tahap pelaksanaan dan tahap akhir pelaksanaan (Darma dkk, 2011).

\section{Tahap Persiapan}

Kegiatan persiapan pelaksanaan diawali dengan pembentukan tim pelaksana kegiatan. Selanjutnya tim pelaksana melakukan rapat untuk berkoordinasi. Tim pelaksana melakukan pertemuan sekaligus koordinasi dengan mitra, untuk mendapatkan masukan dan saran, dilanjutkan dengan membahas persiapan pelaksanaan pelatihan pelaksanaan kegiatan. (Darma dkk, 2011).

\section{Tahap Pelaksanaan}

Pelaksanaan kegiatan, diawali dengan pemberian informasi atau ceramah yang diberikan kepada mitra adalah ceramah tentang nilai gizi donat bakar dan cara pengolahan yang tepat. Hal ini bertujuan untuk memberikan pemahaman tentang donat bakar sebagai bahan baku usahanya. Dengan demikian mereka mampu memanfaatkan dampak positifnya serta mengantisipasi kemungkinan dampak negatif yang mungkin ditimbulkan oleh adanya teknik pengolahan yang kurang baik pada donat bakar (Darma dkk, 2011). Selanjutnya penyerahan peralatan dan bahan kepada mitra. Pada Gambar 1 dapat dilihat penyerahan alat kepada mitra.

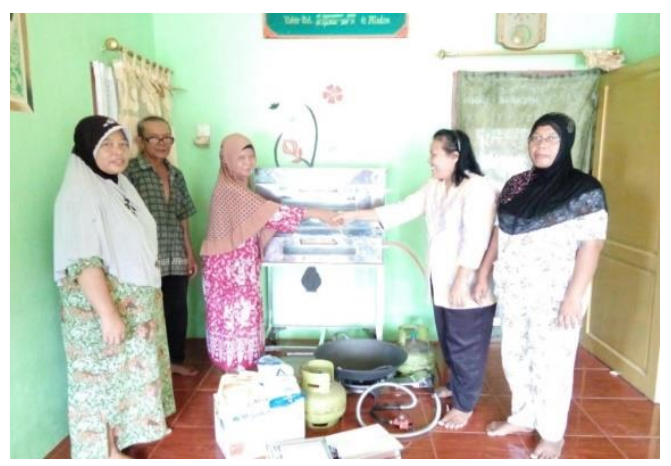

Gambar 1. Serah terima peralatan dan bahan kepada mitra 1

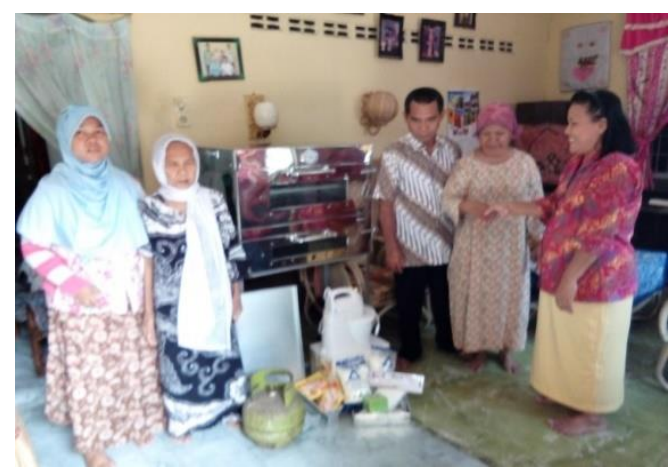

Gambar 2. Serah terima peralatan dan bahan kepada mitra 2

Selanjutnya diadakan pelatihan secara terbimbing adalah pelatihan yang melibatkan tim pelaksana sebagai pendamping sekaligus pembimbing mitra. Sesuai dengan program yang telah direncanakan, dalam pelatihan donat bakar menjadi berbagai aneka rasa. Masing-masing resep dalam pelatihan di berikan kepada mitra, selanjutnya dilakukan praktek secara terbimbing (Darma dkk, 2011). Hal ini dilakukan dengan harapan agar produk yang dihasilkan menjadi sempurna sesuai dengan yang direncanakan.

Pada gambar 3 dapat dilihat Ketua pelaksana sedang menjelaskan penggunaan oven deck kepada mitra 1 . 


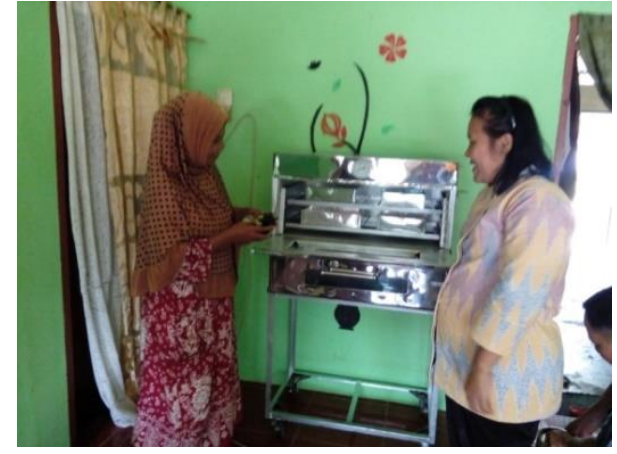

Gambar 3. Ketua pelaksana sedang menjelaskan penggunaan oven deck kepada mitra 1

Kegiatan praktek tembimbing melalui tahapan sebagai berikut (Darma dkk, 2011):

1. Menjelaskan mengenai bahan-bahan yang dibutuhkan dalam satu resep

2. Menyebutkan fungsi dari bahan yang dipergunakan dalam pembuatan pangan.

3. Menentukan peralatan yang digunakan

4. Mendemontrasikan teknik mengolah bahan-bahan yang dipersiapkan sesuai resep yang telah ditentukan

5. Menjelaskan teknik mengemas produk yang dihasilkan agar menjadi lebih menarik dan memiliki nilai plus

6. Menjelaskan bagaimana menentukan hasil produk, baik ditinjau dari bentuk, rasa, aroma maupun terksturnya.

7. Menjelaskan teknik penyajiannya sesuai prinsip/ standar baku.

Pada gambar 4 dan 5 dapat dilihat Mitra 2 sedang membuat adonan donat bakar didampingi ketua pelaksana, dan hasil produk mitra.

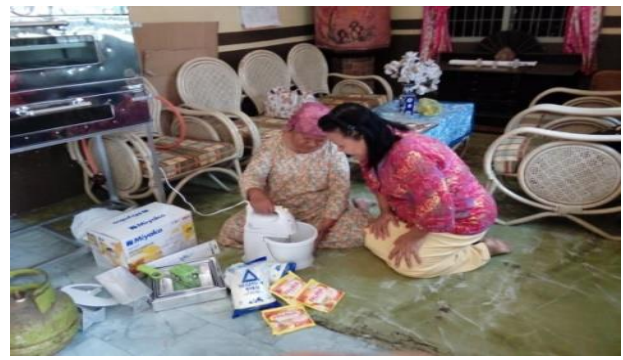

Gambar 4. Mitra 2 sedang membuat donat bakar didampingi ketua pelaksana

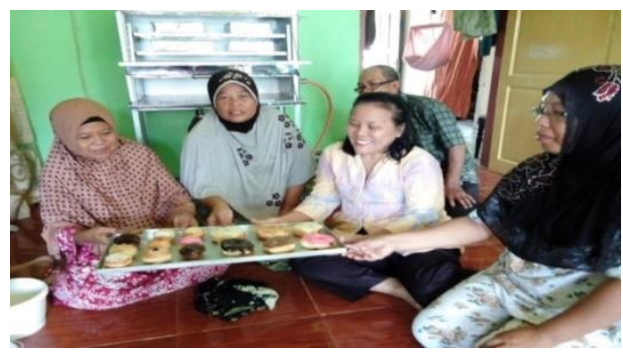

Gambar 5. Ketua pelaksana dan Mitra 1 menunjukkan hasil produksi donat bakar
Terakhir, melakukan pelatihan mandiri yaitu pelatihan yang dilakukan oleh kelompok mitra dengan tetap dievaluasi oleh tim pelaksana. Pada pelatihan mandiri, peran tim pelaksana mulai dikurangi dengan memberikan kesempatan kepada mitra untuk bekerja secara mandiri agar mereka lebih percaya diri dalam menggunakan alat yang di berikan dikemudian hari. Namun demikian mereka tetap bekerja sesuai dengan panduan dalam resep yang telah dibagikan kepada mitra.

Setiap akhir sesi pelatihan dilakukan evaluasi oleh Tim pelaksana. Hal ini dilakukan dengan maksud agar mengetahui tingkat pencapai mitra menyangkut pengolahan pangan yang dipraktekkan. Dengan kata lain apakah mitra dalam praktek secara mandiri/kelompok telah mengikuti tahapan-tahapan yang harus dikerjakan sesuai panduan dalam resep yang telah dibagikan. (Darma dkk, 2011).

Diakhir kegiatan ini, tim pelaksana juga selalu memberikan teknik/trik membuat penganan agar hasilnya menjadi lebih sempurna seperti:

1. Teknik/proses penggunaaan alat agar hasilnya lebih baik

2. Teknik membuat donat bakar membutuhkan kesabaran untuk mendapatkan produk yang maksimal (Darma dkk, 2011).

\section{Tahap Akhir Pelaksanaan}

Setiap akhir pelaksanaan pelatihan dilakukan evaluasi secara bersama oleh Tim pelaksana. Hal ini dilakukan dengan maksud agar dapat diketahui tingkat pencapaian mitra menyangkut pengolahan produk/pangan yang dihasilkan telah sesuai dengan yang telah ditentukan dalam resep yang telah didistribusikan (Darma dkk, 2011).

Pada akhir kegiatan mitra di beri pelatihan penggunaan lebel pada kemasan. Gambar 6 dapat dilihat lebel kemasan donat.

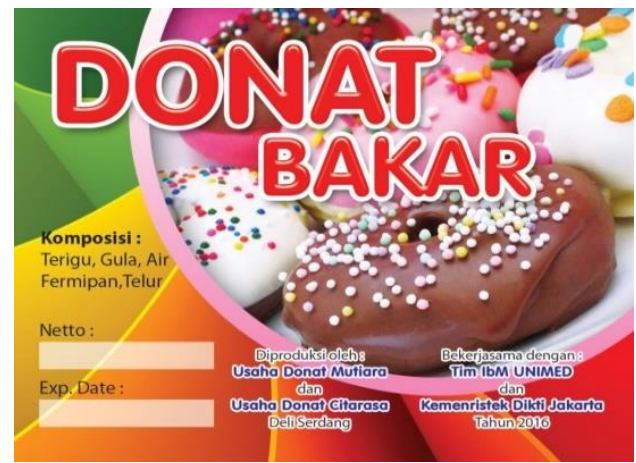

Gambar 6. Label Donat Bakar

\section{KESIMPULAN}

Berdasarkan hasil kegiatan ini maka dapat disimpulkan sebagai berikut :

1. Peralatan yang diberikan kepada mitra dapat mempercepat produksi dan meningkatkan usahanya

2. Pelatihan produksi yang diberikan mampu 
membuka pengetahuan masyarakat dan menciptakan kreasi baru.

3. Pelatihan manajemen usaha dapat memperbaiki pembukuan keuangan dan administrasi mitra.

4. Kegiatan yang dilakukan mampu menjalin kerjasama antara perguruan tinggi dengan masyarakat.

\section{UCAPAN TERIMA KASIH}

Ucapan terima kasih kepada Kemenristek Dikti atas pemberian dana hibah IBM tahun 2016 dan terima kasih kepada LPM Unimed serta kepada mitra yang telah membantu dalam pelaksanaan kegiatan ini.

\section{DAFTAR PUSTAKA}

Anonim. 2015. Mencicipi Manisnya Peluang Bisnis Donat Bakar Nan Legit. Diakses tanggal 18 April 2015.https://www.maxmanroe.com.

Darma Oka. I M, I M. Budiasa, M. Suardani. 2011 Ipteks Bagi Masyarakat Pedesaan Di Desa Tengkudak Penebel Tabanan. Journal Pengabdian Masyarakat. Udayana Mengabdi. vol 10 No.1

Junda Y. 2013. Sukses Peluang Usaha Makanan Koki Instan. Diakses tanggal 18 April 2015. http://www.thekokiinstan.com.

Kusuma DR. 2013. Bisnis Donat Kentang. Diakses tanggal $18 \quad$ April 2015 http://finance.detik.com.

Marantina, Yohana R, Kusumaningtias P, Vebri H. 2015. Bisnis donat masih menjanjikan. Diakses tanggal $\quad 18 \quad$ April 2015. http://peluangusaha.kontan.co.id.

Riyanikusuma.2010. Bisnis Kecil Dan Bauran Pemasaran Pada Produk Donat Bakar. Diakses tanggal 2 Desember 2016. Https://Riyanikusuma.Wordpress.Com

Sekar P. 2013. Manisnya Bisnis Donat Bakar. Diakses tanggal $\quad 18 \quad$ April 2015. http://www.marketing.co.id 